\title{
Triaxial tests on snow at low strain rate. Part I. Experimental device
}

\author{
Markus von MOOS, ${ }^{1,2}$ Perry BARTelt, ${ }^{1}$ Adrian ZWEIDler, ${ }^{2}$ Ernst BLEIKeR ${ }^{2}$ \\ ${ }^{1}$ WSL, Swiss Federal Institute for Snow and Avalanche Research SLF, Flüelastrasse 11, CH-7260 Davos Dorf, Switzerland \\ E-mail: bartelt@slf.ch \\ ${ }^{2}$ Institute for Geotechnical Engineering, Swiss Federal Institute of Technology, ETH-Hönggerberg, CH-8093 Zürich, Switzerland
}

\begin{abstract}
A deformation-controlled triaxial apparatus has been developed in order to investigate the mechanical behaviour of alpine snow. Cylindrical specimens $(58 \mathrm{~mm}$ in diameter, $126 \mathrm{~mm}$ in height) can be axially deformed by applying tensile or compressive strain rates between $2.4 \times 10^{-7} \mathrm{~s}^{-1}$ and $2.4 \times 10^{-2} \mathrm{~s}^{-1}$. Compressed air is used to laterally load the snow specimens with pressures of up to $40 \mathrm{kPa}$. The volumetric deformation is found by carefully encapsulating the snow samples in an airtight Mylar foil and measuring the expelled pore air during sample deformation. The multidimensional stress-strain behaviour can therefore be determined, and constitutive theories of snow advanced. The device is located in the cold rooms of the Weissfluhjoch research station of the Swiss Federal Institute for Snow and Avalanche Research. Some 180 tests have been performed over the last four winters. The density of the snow specimens varied between 190 and $435 \mathrm{~kg} \mathrm{~m}^{-3}$. Part I of this two-part paper discusses the development of the apparatus and the applied testing methodology. Qualitative results are provided. In Part II, a detailed analysis of the results is presented and the viscoelastic properties of snow quantified.
\end{abstract}

\section{INTRODUGTION}

In the past, different geotechnical testing devices have been used to investigate the mechanical properties of snow: simple uniaxial tensile devices (Salm, 1971; Watanabe, 1980; Narita, 1983), centrifuges (Keeler and Weeks, 1967; Gubler, 1978), confined compression oedometers (Abele and Gow, 1975; Yong and Fukue, 1977), direct shear devices (McClung, 1977; Hansen and Brown, 1987; Schweizer, 1998), ram penetrometers (Keeler and Weeks, 1967; Gubler, 1975), shear frames (Keeler and Weeks, 1967; Föhn and others, 1998), viscous rheometers (Camponovo and Schweizer, 2001) and recently micro-penetrometers (Schneebeli and others, 1998).

The above-listed tests are not adequate to formulate mechanical constitutive laws, the most important element of snow pack modelling. They can be used to determine certain values (ultimate tensile and shear strength, material hardness), but they do not provide all the mechanical characteristics required to model a geomaterial (e.g. the relationship between volumetric deformation and applied force). In order to develop advanced constitutive theories, based on the methods presently available (plasticity theory, critical-state soil mechanics, computational inelasticity), the experimental stress response over time as a function of applied deviatoric and volumetric deformation and deformation rates is required. For this purpose, it is customary to apply triaxial testing devices.

In a common triaxial compression test in soil investigations, a constant hydrostatic confining pressure and an axial deformation rate are applied to a sample while the axial stress is measured, i.e. the test is performed in deformationcontrolled mode (Bishop and Henkel, 1962; Lambe and Whitman, 1969). Load-controlled tests are also possible. The cylindrical specimen has a height-to-diameter ratio of larger than two in order to avoid edge effects and create a homogeneous stress state in the sample. The confining pressure is normally applied by water under pressure. The sample is encapsulated in a rubber membrane to ensure that the water does not enter into the pore spaces of the sample (which is usually saturated with water). Measuring the amount of water that flows into or out of the sample allows the volume change of the specimen to be directly determined. Subsequently, the deviatoric deformations can be found and used, along with the volumetric deformations, to describe the complete constitutive behaviour of the material.

Triaxial experiments (Salm, 1977; Desrues and others, 1980; Lang and Harrison, 1995) have also been carried out to determine the multidimensional stress-strain behaviour of snow. In Table 1 an overview of these tests is provided. The triaxial devices, however, had to be either specially constructed or modified in order to work with a fragile, low-density, frozen material like snow. The standard triaxial devices used in soil or rock investigations cannot be directly employed.

Salm (1967, 1971, 1975, 1977) used a triaxial apparatus in which four samples could be tested at the same time: two in axial compression, one in axial tension and the remaining sample under a hydrostatic pressure. The tests were load-controlled. A constant load was applied in steps. Compressed air was used to apply a side pressure of up to $100 \mathrm{kPa}$. The samples were all the same size (diameter $58 \mathrm{~mm}$, height $100 \mathrm{~mm}$ ). The axial deformation and volume change were measured.

Desrues and others (1980) used a standard triaxial apparatus in which a side pressure of $5-30 \mathrm{kPa}$ was applied using an antifreeze--water mixture. The volume change was continually measured using the cell fluid. The experiments 


\begin{tabular}{|c|c|c|c|c|}
\hline & \multicolumn{4}{|c|}{ Study } \\
\hline & Salm $(1967,1971,1975$ 1977) & Desrues and others (1980) & Lang and Harrison (1995) & Bartelt and Von Moos (2000) \\
\hline Triaxial type & Load-controlled & Deformation-controlled & Deformation-controlled & Deformation-controlled \\
\hline Density $\left(\mathrm{kg} \mathrm{m}^{-3}\right)$ & 432 & $150-200$ & $170-376$ & $190-440$ \\
\hline Temperature $\left({ }^{\circ} \mathrm{C}\right)$ & -5.3 & -10 to -2 & -9 to -2 & -12 \\
\hline Strain rate $\left(\mathrm{s}^{-1}\right)$ & $10^{-6}$ to $10^{-4}$ & $10^{-2}$ to $10^{-1}$ & $10^{-5}$ & $10^{-7}$ to $10^{-2}$ \\
\hline Strain range $(\%)$ & $3-30$ & $10-30$ & $15-20$ & $5-20$ \\
\hline Analysis & Power-series stress invariants & Inc. FE law viscoelastic & Critical-state model & Microstructural ice mechanics \\
\hline
\end{tabular}

were deformation-controlled, and both the axial force and axial deformation were recorded. Later, Navarre and others (1987) used an updated apparatus which used compressed air to apply the side pressure. However, they reported that the volume measurements were not accurate. Their samples were the largest (diameter $100 \mathrm{~mm}$, height $150 \mathrm{~mm}$ ) of all triaxial tests. The axial force was measured inside the cell, averting the measurement of friction forces at the cell/loading-shaft interface.

Lang and Harrison (1995) performed deformation-controlled triaxial tests with a modified Norwegian soil apparatus that could apply side pressures of up to $40 \mathrm{kPa}$ with compressed air. The load sensor was placed in the cell. The volume change was measured using a mercury manometer requiring manual observation. The samples were $57.7 \mathrm{~mm}$ in diameter and $149.5 \mathrm{~mm}$ in height.

In the following, we report on the development of a new triaxial apparatus specially designed to develop viscoelastic constitutive laws for snow. The laws will be employed in thermomechanical finite-element (FE) software (Lehning and others, 1998; Bartelt and Christen, 1999). From January 1998 until April 2001, small-strain, low-strain-rate triaxial experiments were carried out on alpine snow with densities of $190-440 \mathrm{~kg} \mathrm{~m}^{-3}$. Some 180 tests were performed at constant temperature $\left(T=-12^{\circ} \mathrm{C}\right)$ but with a wide range of applied strain rates and radial pressures. The microstructure of the samples was quantified using thin-section stereorology before the tests. In Part I of this two-part paper, we discuss the design and use of the apparatus. In the follow-up paper, Part II (Scapozza and Bartelt, 2003), the test results are quantified.

\section{TRIAXIAL APPARATUS}

\subsection{Concept}

The triaxial apparatus was designed to perform axial compressive and tensile tests on cylindrical snow samples with or without a confining side pressure. The deformation rate which can be applied corresponds to the natural creep rate in the alpine snowpack, between $\pm 2.4 \times 10^{-2} \mathrm{~s}^{-1}$ and $\pm 2.4 \times 10^{-7} \mathrm{~s}^{-1}$. A deformation-controlled apparatus was constructed in order to ease the formulation of constitutive laws, which relate strains and strain rates to stresses. Skiers, explosives or vehicles induce higher strain rates; however, these man-made deformation rates were excluded from the design specifications. In order to experimentally simulate a series of natural snowfalls, a further specification was the ability to apply test cycles with differing deformation rates.

Compressed air is used to apply the confining pressure.
The maximum administered pressure $(40 \mathrm{kPa})$ corresponds to extreme natural conditions (snow heights of say $10 \mathrm{~m}$ ). Typically, a confining pressure $<10 \mathrm{kPa}$ is employed. In comparison to air, applying the confining pressure with a fluid is preferable because the measurement of the sample volume change is easier. However, for the case of snow, the use of a fluid is not possible since a hydrostatic pressure difference of the order of $1 \mathrm{kPa}$ from the top to the bottom of the $126 \mathrm{~mm}$ sample is created. Thus, the uniform state of stress and strain in the sample would be disturbed. The measurement of the sample volume change via the pore air is discussed in detail in section 2.3.

Another problem with snow is that the measured forces are small, especially for low-density snow. This means that any frictional forces in the load application system must be minimized. This requirement was met by placing the load cell directly beneath the lower load platen; that is, within the cell. The frictional rubbing forces acting on the loading frame as it passes through the base plate, which must be airtight, are therefore not measured. Stick-slip movements in the loading frame could nonetheless occur. An additional deformation transducer was installed on the loading frame in order to measure the deformation of the sample independently of the prescribed deformation (strain rate). Any stick-slip movements in the load application system would therefore be apparent in the measurements. As will be shown, these were not recorded in the experiments.

The device had to operate at temperatures down to $T=$ $-20^{\circ} \mathrm{C}$. All load cells and pressure transducers had to function accurately at this temperature. More importantly, because the triaxial cell must be airtight, differential thermal straining had to be kept to a minimum. This was accomplished by careful material matching and machine tooling for tight O-ring fits.

The technical specifications of the triaxial apparatus are provided in Table 2 .

\subsection{Mechanical system}

A sketch of the triaxial apparatus is shown in Figure 1. The plan on the left shows the mechanical system; the plan on the right shows the position of the various sensors, which are described in section 2.6.1. The apparatus consists of two primary components: (1) the triaxial apparatus itself, with the airtight cell in which the deformation and confining pressure are applied to the sample, and (2) the volumetric measuring device (see section 2.3). The two components are installed on the same frame and connected via the pore-air system.

In the triaxial apparatus a step motor (400 steps/rev.) (1) is located at the lower end of the driving shaft beneath the cell. The motor propels a screwed spindle (4) over a gearbox 


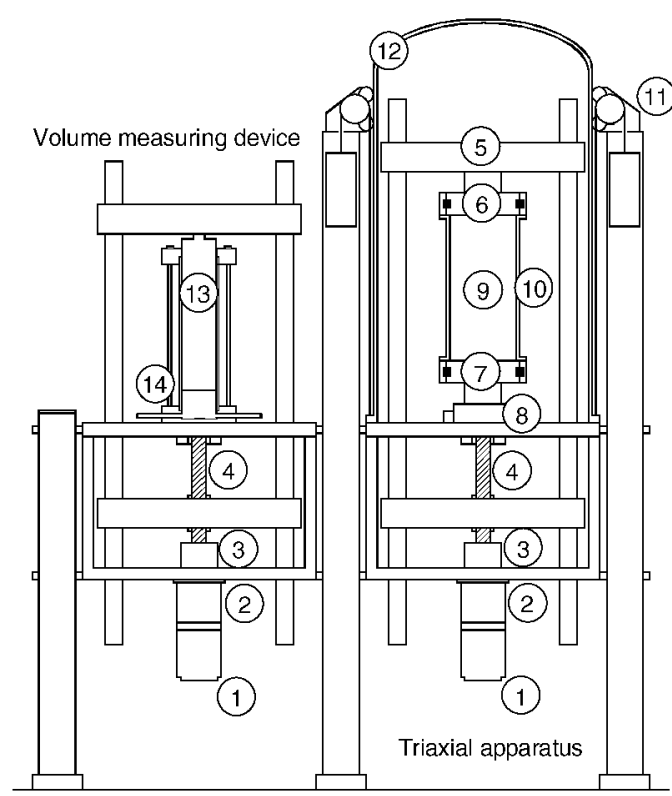

(1) Step motor

(2) Gearbox

(3) Shaft coupling

(4) Screwed spindle

(5) Loading frame

(6) Top load platen

(7) Bottom load platen
(8) Load cell

(9) Snow sample

(10) Membrane

(11) Lifting system

(12) Pressure cell

(13) Piston

(14) Cylinder

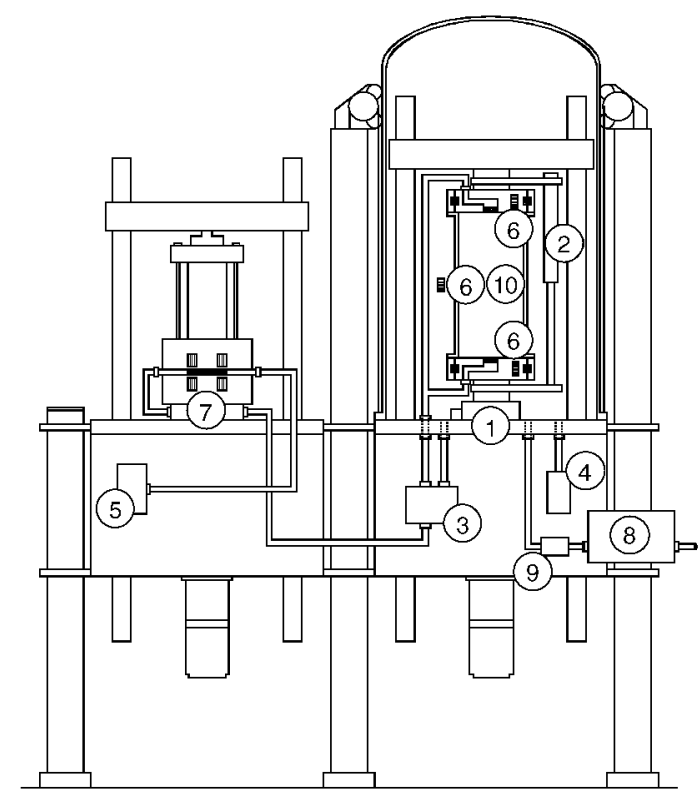

(1) Load cell

(2) Deformation transducer

(3) Differential-pressure gauge

(4) Lateral-pressure gauge

(5) Absolute-pressure gauge

(6) Temperature gauge

(7) Fluid drop between light barriers

(8) Air-pump

(9) Back-pressure valve

(10) Snow sample

Fig. 1. Triaxial apparatus. Left: mechanical system. Right: sensors and pore-air pressure system.

(2) and a shaft coupling (3). The coupling has been introduced to reduce stresses in the driving system. The gearbox has a reduction gear ratio of 16 . The screwed spindle with a pitch of $2 \mathrm{~mm}$ rotates in a satellite roller nut located in the lower cross-beam of the loading frame (5). With this combination of reduction gear ratio and pitch of the screwed spindle, the motor moves the loading frame $0.3 \mu \mathrm{m}$ with one step. The tie bars of the loading frame pass through the base plate of the pressure cell (12) at an airtight interface. At the upper cross-beam of the loading frame the top load platen (6) is fixed. The unmoveable lower load platen (7) is screwed onto the load cell (8) which is fixed to the centre of the base plate. Both load platens are easily exchangeable. For compression tests, load platens with a polished surface are used in order not to hinder the radial straining of the sample. For tension tests, load platens are installed that have a rough surface of sintered metal. These platens can be heated automatically in order to freeze the snow sample onto them. Each load platen has in its centre an $8 \mathrm{~mm}$ diameter filter element which is connected to the pore-air system (see section 2.3 and 2.4). The upper part of the pressure cell (12) is equipped with a counterweight lifting tackle (11) in order to open and close the cell easily without shocking the sample. The pressure cell is sealed to the base plate with an O-ring which is pre-strained when the upper part of the load cell is screwed down to the base plate.

It should be noted that, in contrast to conventional triaxial cells, the load platens are fixed to the loading frame. They cannot transmit the hydrostatic confining pressure to the sample in the axial direction. The measured force is therefore related only to the axial stress and is independent of the applied lateral pressure.

\subsection{Volume-change measurement}

In order to measure the volume change of the sample, the air expelled from the sample during compression is measured. Similarly, the air drawn into the sample during a tensile test can likewise be recorded.

The displaced air flows past the filter into a hose to a Plexiglas pipe with an inner diameter of $2 \mathrm{~mm}$. Within the Plexiglas pipe, a drop of coloured glycol is free to move to the left or right, depending on the direction of the airflow. The drop is located between two light barriers (see Fig. 2). Its length is sufficient to interrupt both barriers. When the sample deforms, the expelled air shifts the position of the drop, so that a light barrier is no longer obstructed. When this occurs, a piston is propelled within a cylinder that is part of the pore-air system (see Fig. 1). The piston moves

Table 2. Technical specifications of triaxial apparatus

\begin{tabular}{lcc}
\hline & Symbol & Value \\
\hline Sample height & $h$ & $126 \mathrm{~mm}$ \\
Sample diameter & $d$ & $58 \mathrm{~mm}$ \\
Max. axial deformation & $\Delta h$ & $\pm 50 \mathrm{~mm}$ \\
Max. axial strain & $\epsilon_{\mathrm{a}, \max }$ & $\pm 40 \%$ \\
Max. deformation rate & $v_{\max }$ & $\pm 3 \mathrm{~mm} \mathrm{~s}^{-1}$ \\
Max. strain rate & $\dot{\epsilon}_{\max }$ & $\pm 2.4 \times 10^{-2} \mathrm{~s}^{-1}$ \\
Min. deformation rate & $v_{\min }$ & $\pm 2.6 \mathrm{~mm} \mathrm{~d}^{-1}$ \\
Min. strain rate & $\dot{\epsilon}_{\min }$ & $\pm 2.4 \times 10^{-7} \mathrm{~s}^{-1}$ \\
Confining pressure & $p_{\mathrm{c}}$ & $0-40 \mathrm{kPa}$ \\
Max. axial force & $P_{\max }$ & $\pm 2 \mathrm{kN}$ \\
Max. axial stress & $\sigma_{\mathrm{a}, \max }$ & $\pm 757 \mathrm{kPa}$ \\
Min. temperature & $T$ & $-20^{\circ} \mathrm{C}$ \\
& &
\end{tabular}




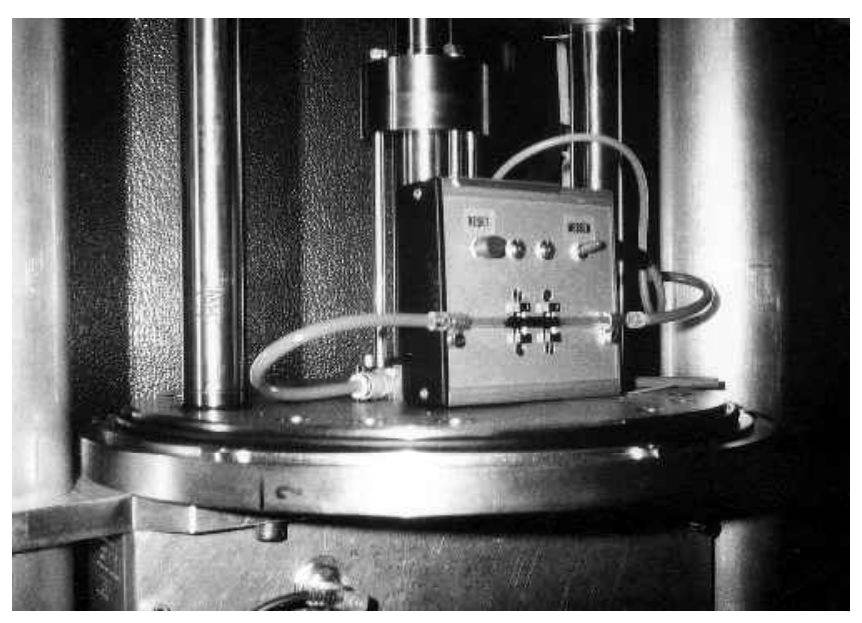

Fig. 2. Between two light barriers a drop of antifreeze has been placed in order to measure the volume of expelled pore air. Behind the light barriers the piston head is visible.

until the drop is back in the original position, obstructing both light barriers. The piston displacement corresponds to the incremental volume change of the sample. This process is repeated step for step until the test ends. The driving unit that propels the piston is similar to that which drives the triaxial apparatus.

An analysis of the test results shows that the accuracy of the measurement is roughly $0.06 \%$ of the total sample volume. This value was determined by measuring the volume of the glycol drop extending past the light barriers. It also determines the step size of the increments in volumetric strain for our measurements.

For a cylindrical sample, the volumetric strain $\epsilon_{\mathrm{v}}$ is composed of both the axial $\epsilon_{\mathrm{a}}$ and radial strains $\epsilon_{\mathrm{r}}$ according to

$$
\epsilon_{\mathrm{v}}=\epsilon_{\mathrm{a}}+2 \epsilon_{\mathrm{r}} .
$$

Since the volumetric and axial strains are measured, the mean radial strain can be determined.

\subsection{Pore-air and lateral pressure systems}

There are two air systems that must be kept separate in order to measure the volume change: the pore-air system of the sample and the lateral pressure system.

The lateral pressure is produced by an air-pump. A pressure transducer measures the cell pressure $p_{\text {cell }}$ relative to the pressure in the pore air, $p_{\text {pore }}$. This value is used by the pressure regulator to control the air-pump and the applied lateral pressure, $p_{\mathrm{c}}$,

$$
p_{\mathrm{c}}=\Delta p_{1}=p_{\text {cell }}-p_{\text {pore }} .
$$

A second pressure transducer measures the lateral pressure relative to the atmospheric pressure,

$$
\Delta p_{2}=p_{\text {cell }}-p_{\text {atm }}
$$

The pore-air system is closed at the beginning of the tests. This ensures that atmospheric pressure changes do not influence the test results. This would especially be the case during long tests over several days. The sample deformation is unhindered because the volume correction in the cylinder maintains a constant pressure in the pore-air system. The pressure is continually checked by a sensor which measures the absolute pressure relative to a vacuum,

$$
\Delta p_{3}=p_{\text {pore }}
$$

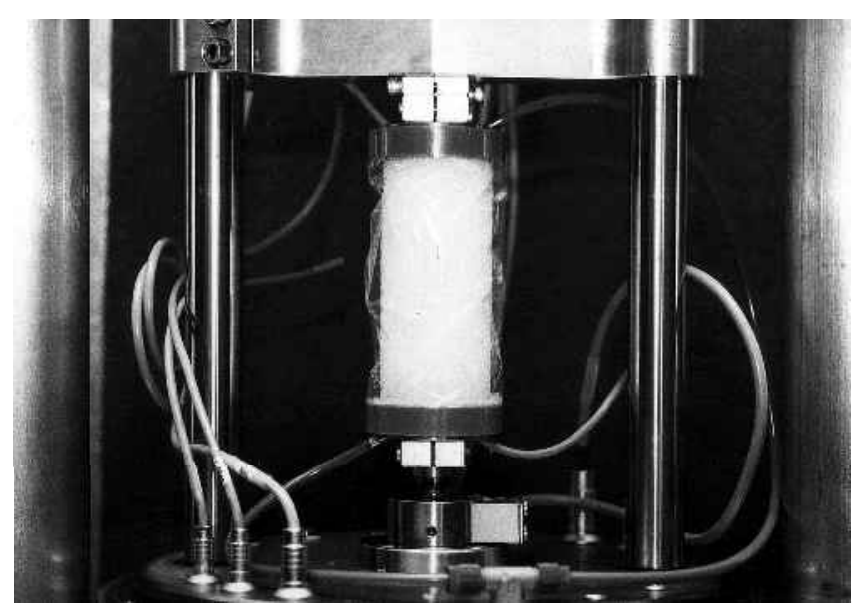

Fig. 3. The encapsulated sample before a confining pressure is applied. Under pressure the membrane folds onto the sample.

The sensors measure $\Delta p_{1}, \Delta p_{2}$ and $\Delta p_{3}$. From these values, $p_{\text {cell }}, p_{\text {pore }}$ and $p_{\text {atm }}$ can be determined.

\subsection{Sample encapsulation}

The snow is encased in a $12 \mu \mathrm{m}$ thick Mylar foil that is airtight (oxygen passage at $0^{\circ} \mathrm{C}: 125 \mathrm{~mL} \mathrm{~m}^{-2}(24 \mathrm{~h})^{-1} \mathrm{MPa}^{-1}$, (manufacturer's specifications)). This ensures that the lateral pressure system is separated completely from the pore-air system. The mechanical properties of the foil remain unchanged at $-20^{\circ} \mathrm{C}$. A cylindrical jacket is made out of a square sheet by adhering the ends of the foil together with a thin $25 \mu \mathrm{m}$ thick layer of glue. The joint is further secured by applying a layer of varnish. The upper and lower ends of the foil are glued to two PVC rings which are fixed to the upper and lower load platens using two O-rings. Silicon grease is used to ensure that the ends of the sample are airtight. The foil is not elastic. Subsequently, instead of a $58 \mathrm{~mm}$ diameter membrane that would fit tightly around the snow sample, a larger $72 \mathrm{~mm}$ diameter membrane is used. Thus, under compression, the radial deformations of the sample are unrestrained. Similarly, the length of the foil must be larger than the sample when tensile tests are performed. Under a confining pressure, the membrane folds neatly onto the sample, applying the pressure directly (see Fig. 3).

Before application, each foil was tested for airtightness over several hours at an applied lateral pressure of $40 \mathrm{kPa}$ by measuring the volume change of a rigid body. If the foil with the greased ends showed a leak $\left(\epsilon_{\mathrm{v}} \neq 0\right)$, the foil was discarded.

\subsection{Electronics}

\subsubsection{Sensors}

In this subsection, the type, position and control of the various sensors are discussed. Numbers in parentheses refer to the numbers listed in Figure 1.

(1) Force. The load cell (1) (Fig. 4) is of type HBM U2. It has a measurement range of $\pm 2 \mathrm{kN}$ with an accuracy of $0.1 \%$. In order to measure larger or smaller forces, the load cell can be easily exchanged.

(2) Displacement. Sample deformation is measured using a HBM W 50 (Hottigner Baldwin Messtechnik (http:// www.hbm.de) displacement sensor. The sensor is 


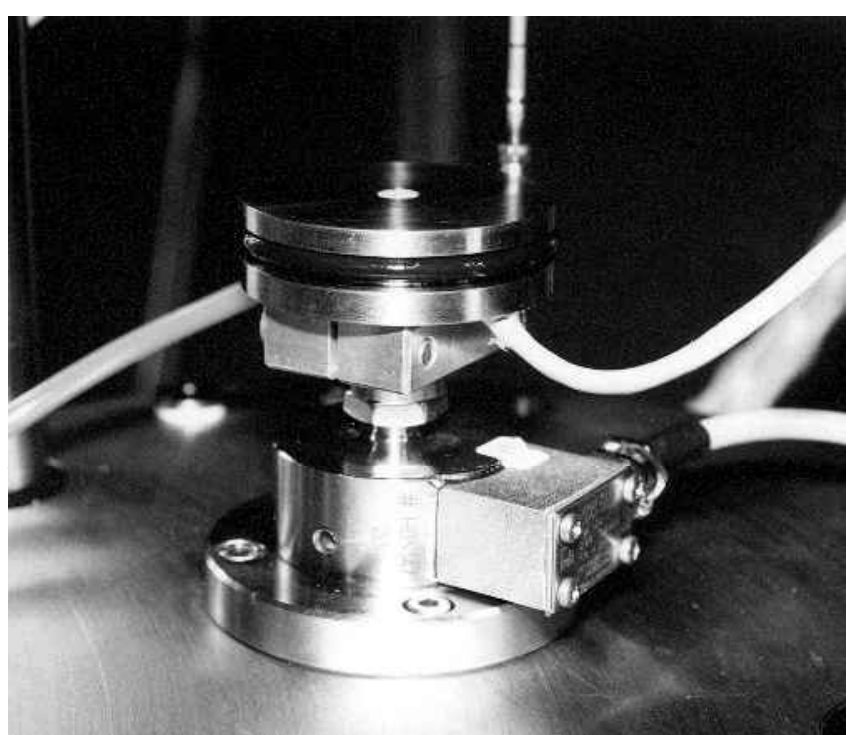

Fig. 4. The load cell and fixed lower load platen. A small air filter is located in the centre of the platen. One cable is attached to a temperature sensor; the second tube transports expelled pore air.

located in the upper load platen and can measure the changes in sample height between 0 and $100 \mathrm{~mm}$ with an accuracy of $0.2 \%$.

(3) Pressure. As stated in section 2.4, the pore and confining air systems are controlled using three pressure sensors. The pressure sensor (3) that measures the difference between the confining and pore pressure $\left(\Delta p_{1}\right)$ is of type Keller PD11 (maximum pressure $50 \mathrm{kPa}$, error of $0.2 \%$ ). It is located under the base plate of the pressure cell. The lateral-pressure sensor (4) is of type Keller PR11 (maximum pressure $50 \mathrm{kPa}$, error of $0.2 \%$ ) and has been installed directly in the base plate of the pressure cell. The absolute-pressure sensor (5), which measures the pore-air pressure $p_{\text {pore }}$, is a Setra 204 (maximum pressure $170 \mathrm{kPa}$, error of $0.07 \%$ ).

(4) Temperature. The temperature distribution in the snow sample is controlled by three Minco temperature sensors of type PT $100 \mathrm{~S} 202 \mathrm{PD}\left(-45^{\circ}\right.$ to $100^{\circ} \mathrm{C}$, error of $\left.0.3 \%\right)$. One sensor has been placed in each of the load platens. The third sensor is located free in the triaxial cell, and measures the temperature of the confining air.

The quoted errors are based on the manufacturer's specifications. However, in advance of a testing programme (before every winter), all force, temperature and pressure sensors were calibrated with reference measurements over the entire testing range (force, temperature and lateral pressure). For example, the load cell was calibrated by placing a second load cell between the platens. The second cell was obtained from the official Swiss testing society and was valid over the entire load and temperature range.

\subsubsection{Control system}

The apparatus contains two separate step motors and subsequently two separate control systems that are connected to a PC over a RS-232 interface. The first is for the applied deformation and the second is for the volume-change measurement.

The analog signals from the sensors are sent to a single control unit containing the sensor amplifiers and confining-

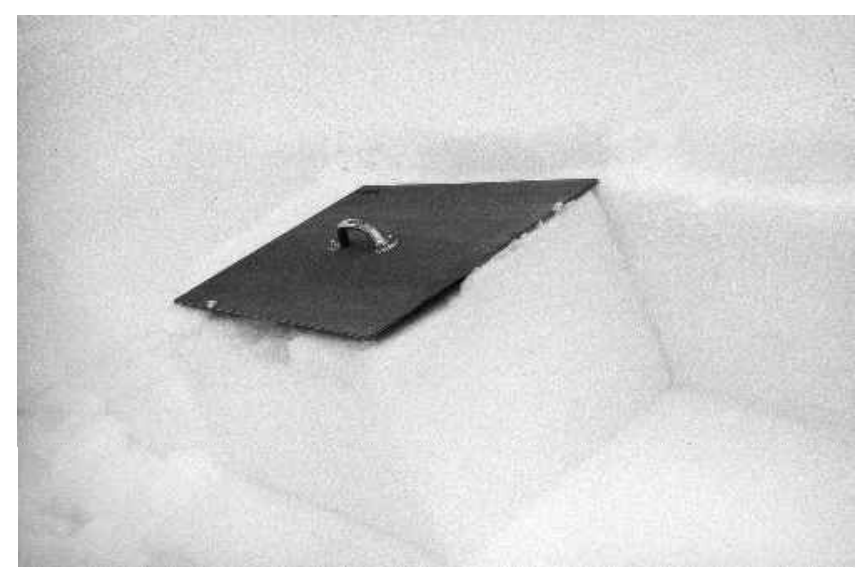

Fig. 5. A snow block is cut from the snowpack. It was transported to the cold rooms and stored at constant temperature before specimens were cut out.

pressure regulation unit. The data are then sent to a $\mathrm{PG}$ via an analog/digital converter (16 channel $\mathrm{A} / \mathrm{D} \pm 10 \mathrm{~V}, 16$ bits).

A program was developed (with LABVIEW version 5.1) to specify the test parameters and display the measurement results. The deformation rate (in $\mathrm{mm} \mathrm{s}^{-1}$ to $\mathrm{mm} \mathrm{d}^{-1}$ ) must be specified. Deformation cycles are applied to the sample by inputting a sequence of deformation rates and corresponding deformations. An additional wait cycle has been introduced to study sample stress relaxation.

The program interface selectively displays the recordings of all sensors in real time. This feature is especially helpful at the beginning of the test when the upper load platen deforms the sample for the first time. At this instant, the deformation is stopped and the sample relaxes. When the measured load reaches zero (seen on the display), the sample is deformed with the specified strain rate.

\section{TESTS}

\subsection{Test samples}

The snow was gathered from the Weissfluhjoch test site (2540 m a.s.l.) as well as at the Flueela mountain pass (2060 ma.s.l.) (Fig. 5). Special attention was paid to withdrawing samples from homogeneous snow layers. Since layers of $126 \mathrm{~mm}$ are rare, this meant that the samples were cut out horizontally. Because all the samples were extracted in one way, no experiments could be performed to test isotropy. The gathered snow blocks were stored in airtight containers at $-12^{\circ} \mathrm{C}$ before the samples were prepared for testing.

From the stored snow blocks, samples with a diameter of $58 \mathrm{~mm}$ and a height of $126 \mathrm{~mm}$ were cut out using a specialpurpose drill. The drill cores were then placed in a specialpurpose cylinder in order to cut flat parallel top and bottom surfaces (see Fig. 6). The geometric tolerance was within one or two grain diameters. The sample volume was exactly onethird of a litre. Immediately before the samples were placed into the apparatus, the density of the snow was determined.

Once the sample was fully installed in the testing machine, a $2-4 \mathrm{kPa}$ axial stress was applied. The load platens were moved at a rate of $1 \mathrm{~mm} \mathrm{~min}^{-1}$ until a resisting force was measured. The force results from single grain deformations at the upper and lower surfaces of the samples. At this point, the deformation was immediately stopped and the resulting strain 


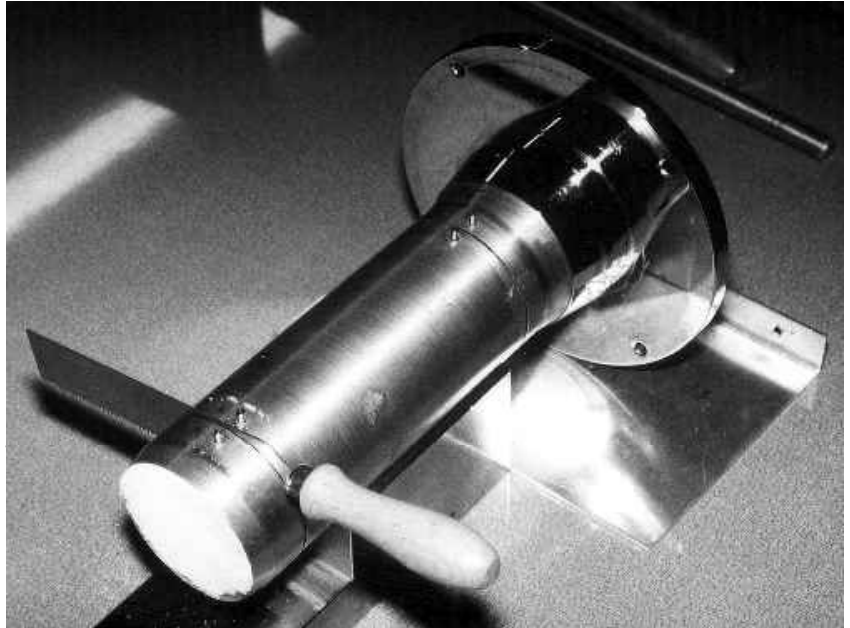

Fig. 6. Cutting the specimen.

maintained at a constant value for several hours. This ensured that the sample was seated squarely in the load platens, and any mismatch between the platens and the sample was eliminated. This period also allowed the sample temperature to reach equilibrium with the room temperature and allowed the stress to relax to a zero value. Although this procedure is not ideal because the sample is predeformed, it is unavoidable for a porous granular material like snow. The forces measured at the beginning of the test do not reflect the bulk deformation of the material, but rather surface effects.

At the end of this period, we defined the axial strain $\epsilon_{\mathrm{a}}=$ 0 and stress $\sigma_{\mathrm{a}}=0$. The confining pressure was then applied to the sample via the cell pressure. At the same time, the axial stress was regulated such that $\sigma_{\mathrm{a}}=p_{\mathrm{c}}$. Thus, the experiments began from a hydrostatic state of stress. The application times were typically of the order 5-10 s. Immediately afterwards, the axial deformation at the specified rate was applied to the sample. The confined pressure was held constant over the duration of the test.

\subsection{Microstructure}

Several samples were preserved in diethyl phthalate in order to make a series of thin sections, which were used to characterize the test material. Serial cuts of the samples were manufactured on a microtome at a spacing of $0.03 \mathrm{~mm}$. The thin sections were then digitalized in order to determine the microstructural parameters. See Good (1987) for a complete
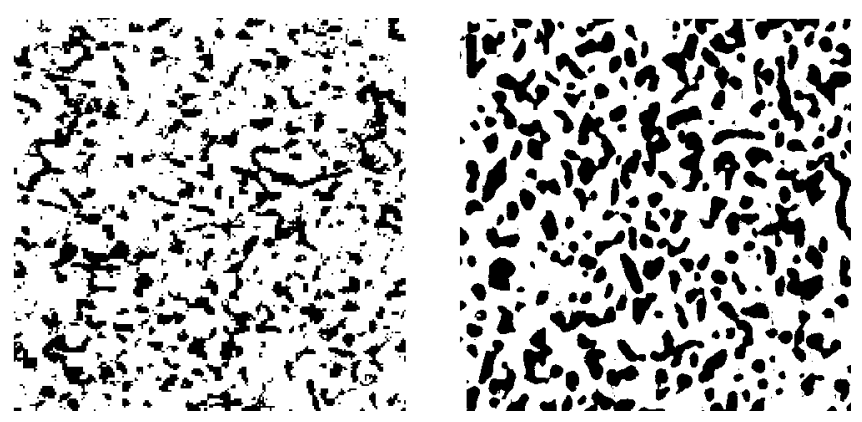

Fig. 7. Two thin sections $(7.5 \mathrm{~mm} \times 7.5 \mathrm{~mm})$. The sample on the left ( sample 2) has density $192 \mathrm{~kg} \mathrm{~m}^{3}$; the sample on the right ( sample 10) has density $323 \mathrm{~kg} \mathrm{~m}^{3}$.
Table 3. Summary of microstructure analysis

\begin{tabular}{cccccc}
\hline Sample No. & $\begin{array}{c}\text { Density } \rho \\
\mathrm{kg} \mathrm{m}^{-3}\end{array}$ & $\begin{array}{c}\text { Grain radius } r_{\mathrm{g}} \\
\mathrm{mm}\end{array}$ & $\begin{array}{c}\text { Bond radius } \mathrm{r}_{\mathrm{b}} \\
\mathrm{mm}\end{array}$ & $N_{2}$ & $N_{3}$ \\
& & & & & \\
\hline 1 & 192 & 0.088 & 0.030 & 0.5 & 1.6 \\
2 & 193 & 0.102 & 0.027 & 0.6 & 2.8 \\
3 & 194 & 0.097 & 0.022 & 0.5 & 3.0 \\
4 & 203 & 0.116 & 0.037 & 0.6 & 2.5 \\
5 & 310 & 0.110 & 0.025 & 0.7 & 4.0 \\
6 & 316 & 0.118 & 0.031 & 0.7 & 3.6 \\
7 & 326 & 0.124 & 0.039 & 0.8 & 3.3 \\
8 & 328 & 0.129 & 0.042 & 0.8 & 3.4 \\
9 & 345 & 0.140 & 0.044 & 0.8 & 3.3 \\
10 & 323 & 0.143 & 0.068 & 0.9 & 2.6 \\
11 & 322 & 0.102 & 0.046 & 0.9 & 2.3 \\
\hline
\end{tabular}

description of this technique. Two examples are shown in Figure 7.

The grains were rounded and had a diameter of typically $0.25 \mathrm{~mm}$. No temperature-gradient faceted snow types were found. An overview of the microstructure samples is shown in Table 3.

The mean grain radius, $r_{\mathrm{g}}$, was determined from the thin sections, assuming that the grains were spherical. The mean bond radius, $r_{\mathrm{b}}$, was found, assuming a circular bond cross-section. The mean two-dimensional coordination number, $N_{2}$ was also extracted from the thin sections. Then, using the method of Alley (1986), the three-dimensional coordination number was calculated. Both $N_{2}$ and $N_{3}$ are shown in Table 3.

\subsection{Test series}

Compression, tension and cyclic compression tests (with different deformation rates) were performed. The density and microstructure of the samples varied, as well as the applied strain rate and confining pressure. The temperature of all experiments was fixed at $T=-12^{\circ} \mathrm{C}$. Three typical examples are provided. A complete catalogue of all the tests in 1998 and 1999 is contained in Von Moos (2000). The examples are: a simple compression test (Fig. 8a), a tensile test (Fig. 8b) and a cyclic compression test (Fig. 8c). The graphs depict the axial stress and volume change over time. Positive stresses are compressive.

\section{DISGUSSION OF TEST RESULTS}

In the following, the influence of strain rate, snow density and confining pressure on the measured axial stress is presented in general. The goal is to demonstrate the performance of the triaxial apparatus.

Consider Figure 9, which displays the results of two single cycle compression tests with the same applied strain rate $\left(7.4 \times 10^{-7} \mathrm{~s}^{-1}\right)$ and confining pressure $\left(p_{\mathrm{c}}=5 \mathrm{kPa}\right)$, but with different densities $\left(423\right.$ and $247 \mathrm{~kg} \mathrm{~m}^{-3}$ ). The material behaviour depicted in Figure 9 shows that snow density has a considerable effect on the measured response. The higher-density snow produces a 10 times larger yield stress. Furthermore, the lower-density snow approaches the yield stress more smoothly; moreover, the higher-density specimen has a clearly defined yield stress. Low-density snow exhibits a more non-linear stress-strain response than higher-density snow. 

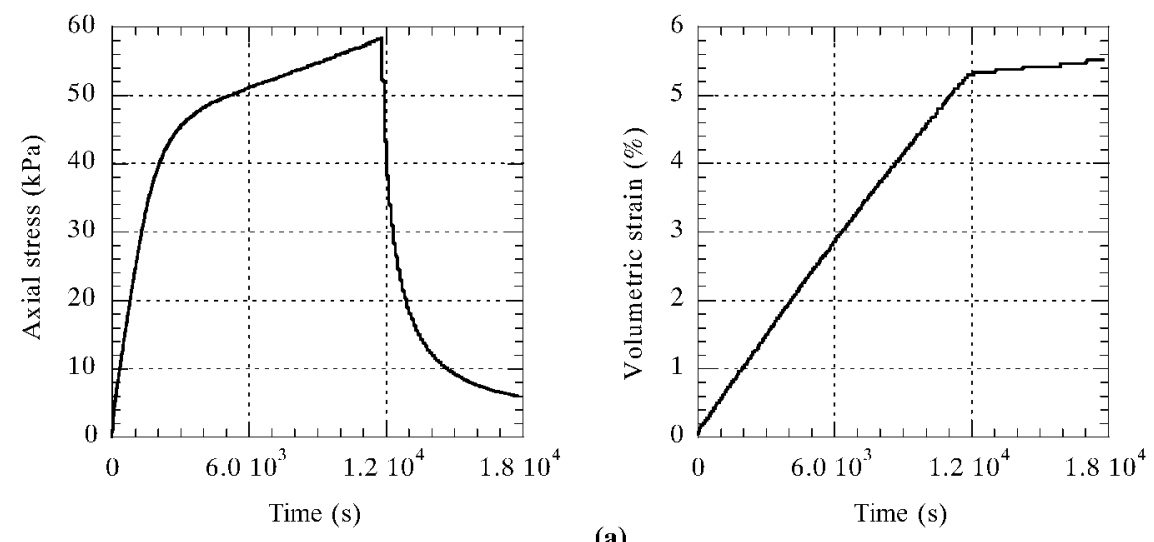

(a)
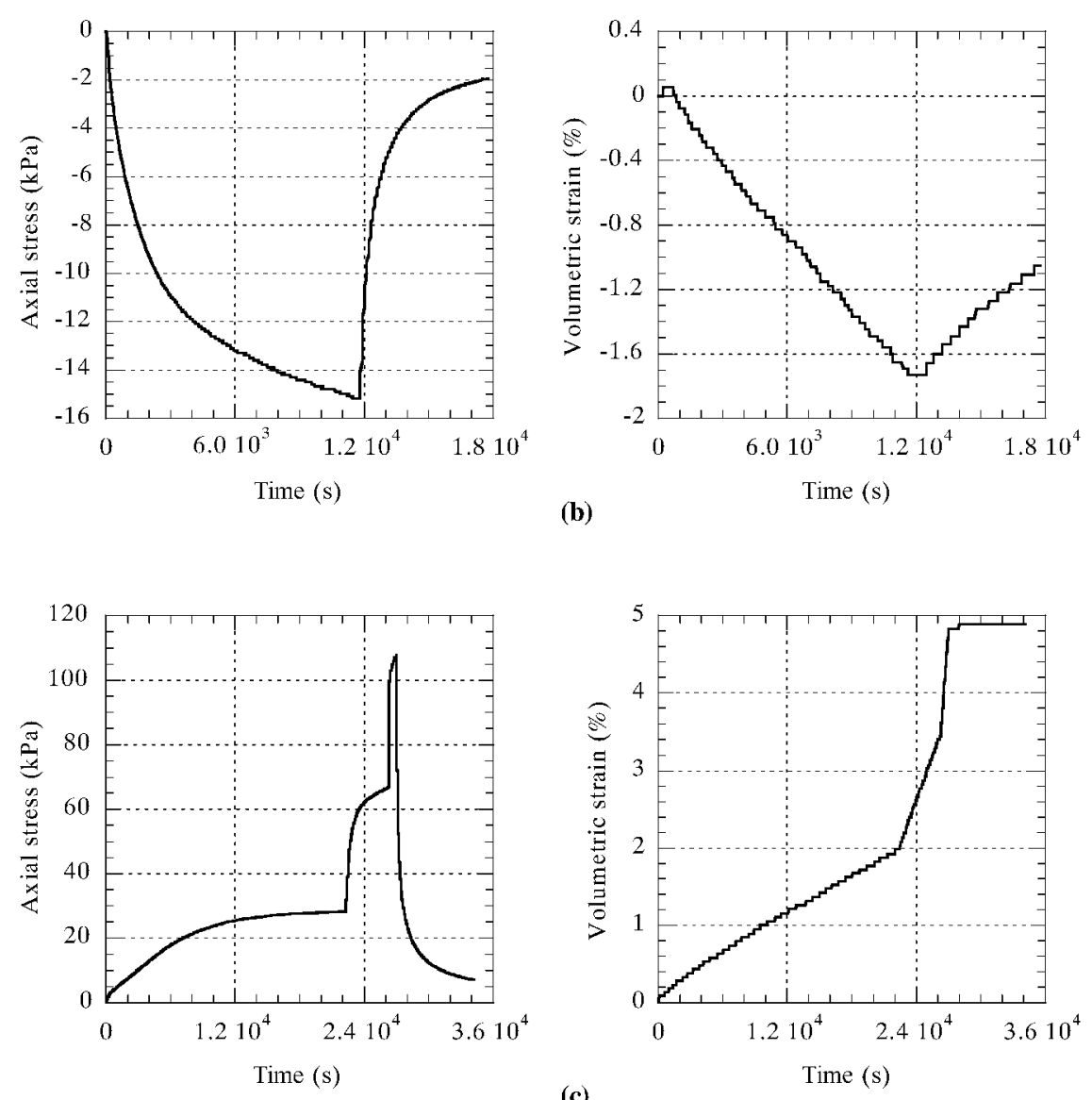

Fig. 8 . Measured axial stress and volumetric strain as a function of time in (a) a compression test $\left(\dot{\epsilon}=4.2 \times 10^{-\sigma_{s}-1}, p_{\mathrm{c}}=\right.$

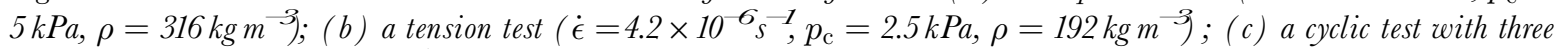
deformation rates $\left(\dot{\epsilon}_{1}=7.4 \times 10^{-7} \mathrm{~s}^{-1}, \dot{\epsilon}_{2}=4.2 \times 10^{-\sigma_{s}^{-1}}\right.$ and $\left.\dot{\epsilon}_{3}=2.2 \times 10^{-5} s^{-1}, p_{\mathrm{c}}=2.5 \mathrm{kPa}, \rho=314 \mathrm{~kg} \mathrm{~m}^{-3}\right)$.

Stress-strain curves of three separate experiments with varying strain rates $\left(4.2 \times 10^{-6} \mathrm{~s}^{-1}, 1.1 \times 10^{-5} \mathrm{~s}^{-1}, 2.2 \times 10^{-5} \mathrm{~s}^{-1}\right)$ are superimposed in Figure 10. The lateral pressure $\left(p_{\mathrm{c}}=\right.$ $0 \mathrm{kPa})$ and temperature $\left(T=-12^{\circ} \mathrm{C}\right)$ remained constant; the densities of the three samples were approximately equal $\left(184,189\right.$ and $\left.192 \mathrm{~kg} \mathrm{~m}^{-3}\right)$. The picture depicts the increasing yield stress $\sigma_{\mathrm{y}}$ with increasing strain rate, $\dot{\epsilon}_{\mathrm{a}}$, characteristic of viscoelastic material behaviour. Note that the responses are well rounded, typical of low-density snow.

The samples were deformed up to $5 \%$ strain and then the samples were allowed to relax. The hardening rate reached after the $2 \%$ strain is approximately the same for all three experiments and is independent of the strain rate.

A series of tests under the same test conditions (strain rate and confining pressure) was carried out on nine snow samples in order to test the repeatability of the experiments. Figure 11 shows the measured axial stress of three experiments in which the density of the samples differed only slightly $\left(376,382\right.$ and $\left.390 \mathrm{~kg} \mathrm{~m}^{-3}\right)$, but the strain rate $\left(2.2 \times 10^{-5} \mathrm{~s}^{-1}\right)$, lateral pressure $\left(p_{\mathrm{c}}=5 \mathrm{kPa}\right)$ and temperature $\left(T=-12^{\circ} \mathrm{C}\right)$ remained constant. Figure 11 shows how sensitive the yield stress is to small variations in density. The almost ideal elastic-plastic response of all three curves is typical of high-density snow. The tests were performed quickly before the samples had time to change their microstructure.

Figure 12 illustrates the effect of confining pressure on the experimental results. Different confining pressures (0,2.5 and 

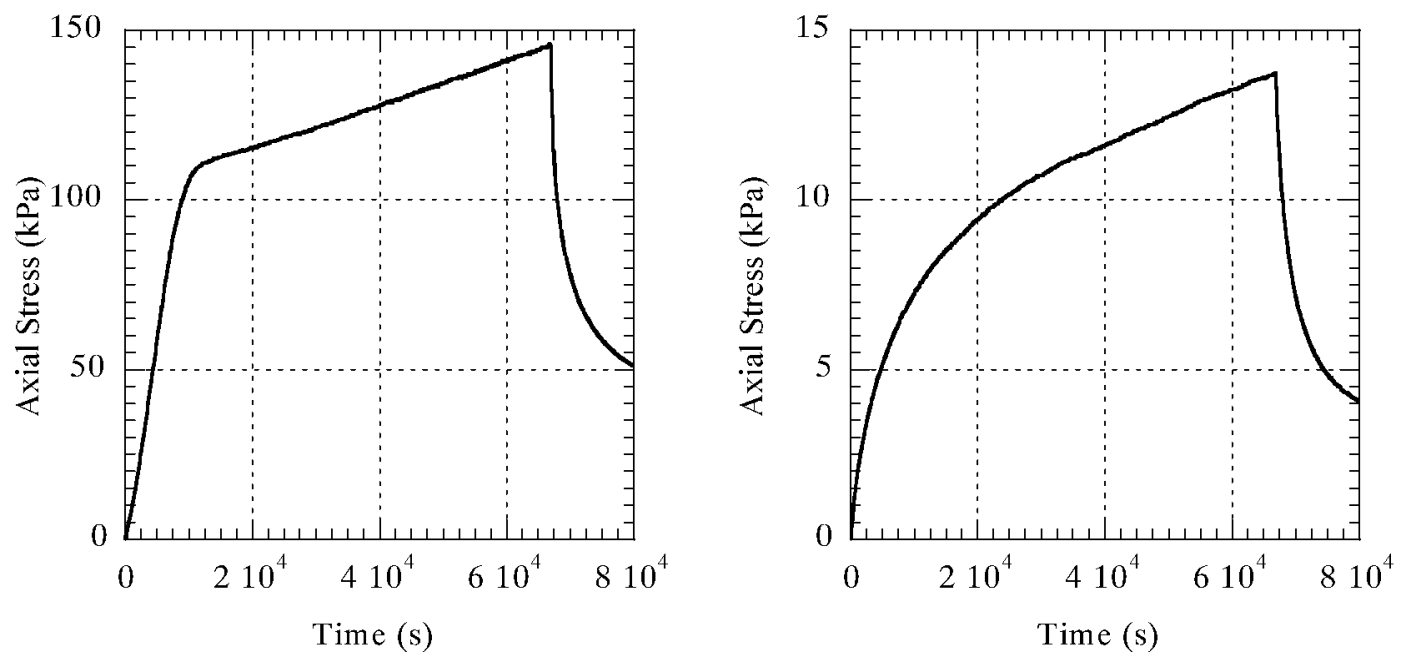

Fig. 9. Influence of snow density on the measured axial stress. The density of the specimen on the left was $423 \mathrm{~kg} \mathrm{~m}^{-3}$; on the right $247 \mathrm{~kg} \mathrm{~m}^{-3}$. The lateral pressure and applied strain rate for both tests was the same: $p_{\mathrm{c}}=5 \mathrm{kPa}$ and $7.4 \times 10^{-7} \mathrm{~s}^{-1}$, respectively. The axial stress differs by a factor 10. More importantly, the shape of the response differs significantly.

$5.0 \mathrm{kPa}$ ) were applied to three samples of nearly equal density $\left(311,316\right.$ and $\left.316 \mathrm{~kg} \mathrm{~m}^{-3}\right)$. The samples were deformed with the same strain rate $\left(7.4 \times 10^{-7} \mathrm{~s}^{-1}\right)$ at constant temperature $(T=$ $-12^{\circ} \mathrm{C}$ ). The axial stress increases with increasing pressure. The confining pressure also induces radial creep, which can be determined from the volumetric measurements, according to Equation (1). The samples did not radially bulge and often showed a compressive radial creep under the applied confining pressure.

\section{GONCLUSIONS}

Several technical problems were overcome during the design and construction of the presented triaxial apparatus. These include the application of lateral pressure with air, the measurement of volumetric deformations, the airtight encapsulation of the test samples and the application of natural snowcover deformation rates with little or no friction. As is shown in the companion paper (Scapozza and Bartelt, 2003), valuable information concerning the mechanical behaviour of snow has been obtained. The compressive viscosity and elastic response have been quantified over a wide range of densities and strain rates. The activation energy of snow as a function of density and temperature has also been determined (Scapozza and Bartelt, in press).

An important design feature that can be questioned is the deformation-controlled test procedure. Deformation-controlled tests are advantageous when developing constitutive theories in porous materials because the microstructural strain state is similar to the applied bulk strain. This simplifies the development of microstructure-based constitutive theories (Kry, 1975; St. Lawrence and Bradley, 1975; Gubler, 1978) where the deformation of the ice matrix is modelled as polycrystalline ice (Hansen and Brown, 1987; Mahajan and Brown, 1993; Bartelt and Von Moos, 2000). In its natural state, however, snow exists under self-weight. Load-controlled tests are therefore necessary. They have the additional advantage that the elastic and viscous parts of the total deformation are easily identified.

A triaxial apparatus is employed in soil- and icemechanics investigations to determine the bulk volumetric and deviatoric properties of the material. Because the microstructural stress state in the load-bearing chains, which controls the mechanical behaviour of the specimen, does not

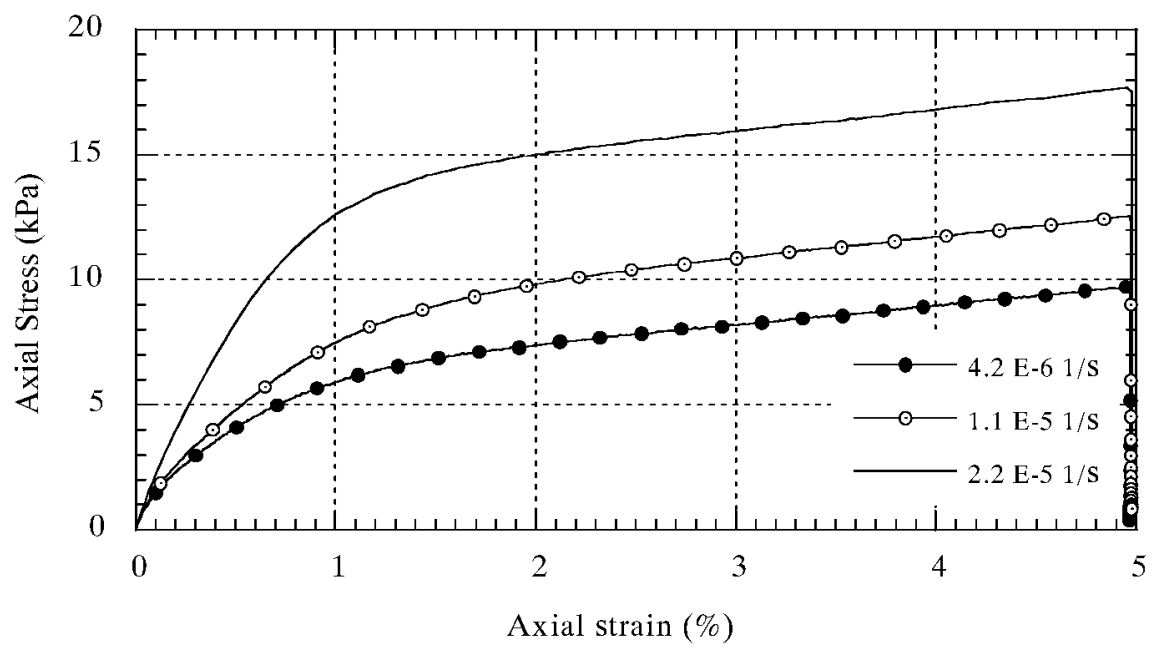

Fig. 10. Increasing axial stress $\sigma_{\mathrm{a}}$ with increasing strain rate. The density of all three samples was approximately equal, $\rho \approx 190 \mathrm{~kg} \mathrm{~m}^{3}$. 


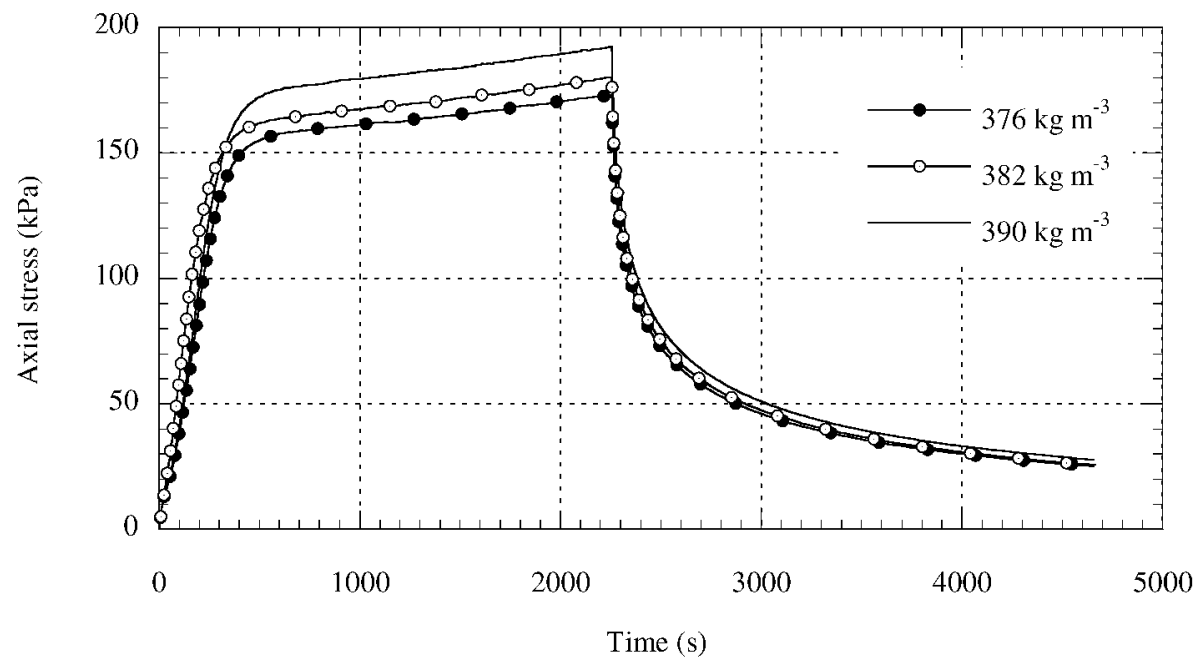

Fig. 11. Influence of small variations in snow density on measured axial stress. Three samples of density 376,382 and $390 \mathrm{~kg} \mathrm{~m}^{-3}$ were deformed with a rate of $2.2 \times 10^{-5} s$.

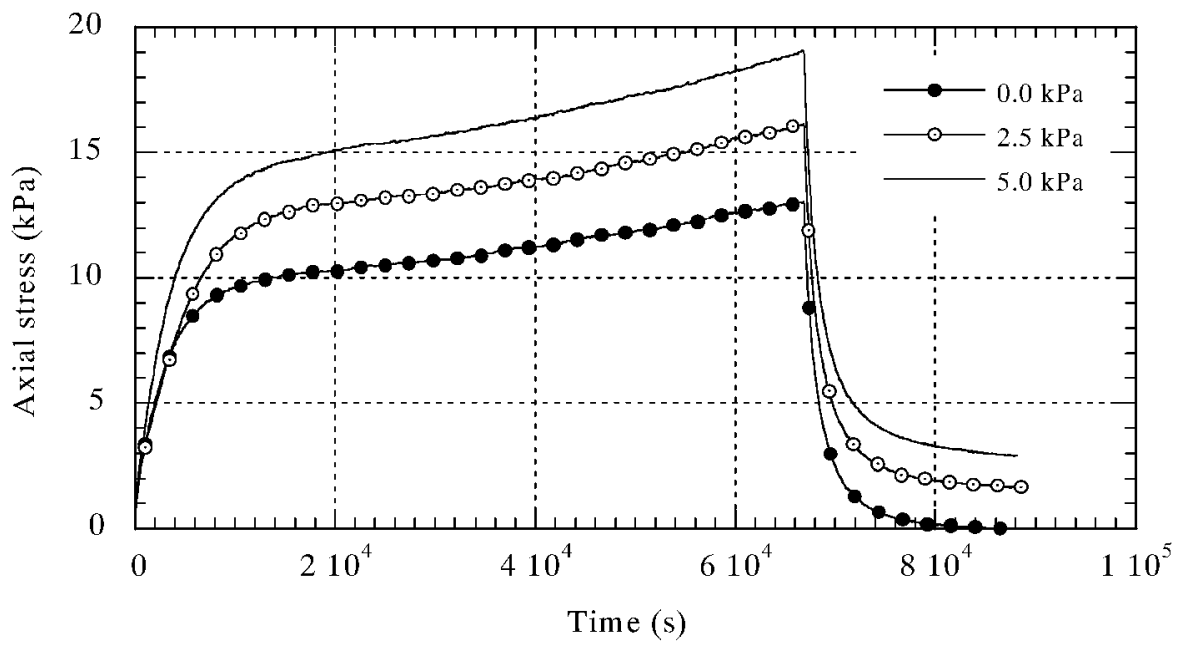

Fig. 12. The influence of confining pressure on the measured axial stress. Three samples of nearly equal density (311, 316 and $316 \mathrm{~kg} \mathrm{~m}{ }^{3}$ were deformed with a strain rate of $7.4 \times 10^{-7} \mathrm{~s}^{-1}$ at constant temperature.

correspond to the bulk stress state, the shear and normal stress responses cannot be related by continuum mechanics laws. Therefore, it is not possible to determine the shear properties of snow with a triaxial apparatus. In order to determine the shear response, simple or direct shear tests are still required.

Two further aspects of mechanical snow testing could not be resolved with the triaxial apparatus. Firstly, the lowest tested density of $190 \mathrm{~kg} \mathrm{~m}^{-3}$ is still high in comparison to new snow densities of the order of $100 \mathrm{~kg} \mathrm{~m}^{-3}$. Because of handling problems, the mechanical properties of new snow remain difficult to determine in laboratory experiments. Secondly, although tensile tests can be performed with the triaxial apparatus, samples under tensile load often broke at the platen/sample interface, providing no information. Improved tensile testing procedures are still required.

\section{ACKNOWLEDGEMENTS}

The authors would like to thank the Swiss National Science Foundation for financially supporting this work. In addition, the authors thank W. Ammann, head of Swiss Snow and Avalanche Research, and P. Amann and F. Bucher of the Institute for Geotechnical Engineering, Swiss Federal Institute of Technology, for their support. Finally, B. Salm was especially helpful during the design of the triaxial apparatus, thanks to his many years of experience with triaxial testing.

\section{REFERENCES}

Abele, G. and A. J. Gow. 1975. Compressibility characteristics of undisturbed snow. CRREL Res. Rep. 336.

Alley, R. B. 1986. Three-dimensional coordination number from twodimensional measurements: a new method. F. Glaciol., 32(112), 391-396.

Bartelt, P. and M. Christen. 1999. A computational procedure for instationary temperature-dependent snow creep. In Hutter, K., Y. Wang and H. Beer, eds. Advances in cold-region thermal engineering and sciences: technological, environmental, and climatological impact. Berlin, etc., Springer-Verlag, 367386. (Lecture Notes in Physics 533.

Bartelt, P. and M. von Moos. 2000. Triaxial tests to determine a microstructure-based snow viscosity law. Ann. Glaciol., 31, 457-462.

Bishop, A.W. and D. J. Henkel. 1962. The measurements of soil properties in triaxial tests. Second edition. London, The English Language Book Society.

Camponovo, C. and J. Schweizer. 2001. Rheological measurements of the viscoelastic properties of snow. Ann. Glaciol., 32, 44-50.

Desrues, J., F. Darve, E. Flavigny, J. P. Navarre and A. Taillefer. 1980. An incremental formulation of constitutive equations for deposited snow. 7. Glaciol., 25(92), 289-307.

Föhn, P. M. B., C. Camponovo and G. Krüsi. 1998. Mechanical and structural properties of weak snow layers measured in situ. Ann. Glaciol., 26, 1-6.

Good, W. 1987. Thin sections, serial cuts and 3-D analysis of snow. International Association of Hydrological Sciences Publication 162 (Symposium at Davos 1986 - Avalanche Formation, Movement and Effects ), 35-48.

Gubler, H. U. 1975. On the Rammsonde hardness equation. International 
Association of Hydrological Sciences Publication 114 (Symposium at Grindelwald 1974 - Snow Mechanics), 110-121.

Gubler, H. 1978. Determination of the mean number of bonds per snow grain and of the dependence of the tensile strength of snow on stereological parameters. F. Glaciol., 20 (83), 329-341.

Hansen, A. C. and R. L. Brown. 1987. A new constitutive theory for snow based on a micromechanical approach. International Association of Hydrological Sciences Publication 162 (Symposium at Davos 1986-Avalanche Formation, Movement and Effects), 87-104.

Keeler, C. M. and W. F. Weeks. 1967. Some mechanical properties of Alpine snow, Montana 1964-66. CRREL Res. Rep. 227.

Kry, P. R. 1975. The relationship between the visco-elastic and structural properties of fine-grained snow. F. Glaciol., 14(72), 479-500.

Lambe, T.W. and R.V. Whitman. 1969. Soil mechanics. New York, etc., John Wiley and Sons.

Lang, R. M. and W. L. Harrison. 1995. Triaxial tests on dry, naturally occurring snow. Cold Reg. Sci. Technol., 23(2), 191-199.

Lehning, M., P. Bartelt and B. Brown. 1998. Operational use of a snowpack model for the avalanche warning service in Switzerland: model development and first experiences. In Hestnes, E., ed. 25 Years of Snow Avalanche Research, Voss 12-16 May 1998. Proceedings. Oslo, Norwegian Geotechnical Institute, 169-174. (NGI Publication 203.)

Mahajan, P. and R. L. Brown. 1993. A microstructure-based constitutive law for snow. Ann. Glaciol., 18, 287-294.

McClung, D. M. 1977. Direct simple shear tests on snow and their relation to slab avalanche formation. F. Glaciol., 19(81), 101-109.

Narita, H. 1983. An experimental study on tensile fracture of snow. Contrib. Inst. Low Temp. Sci., Ser. A 32,1-37.

Navarre, J. P., A. Taillefer, E. Flavigny, J. Desrues and T. Gauthier. 1987. Mécanique de la neige. Essais en laboratoire sur la résistance de la neige. International Association of Hydrological Sciences Publication 162 (Symposium at Davos 1986 - Avalanche Formation, Movement and Effects), 129-137.
St. Lawrence, W. and C. C. Bradley. 1975. Deformation of snow in terms of a structural mechanism. International Association of Hydrological Sciences Publication 114 (Symposium at Grindelwald 1974 - Snow Mechanics), 155-170.

Salm, B. 1967. An attempt to clarify triaxial creep mechanics of snow. In Ōura, H., ed. Physics of snow and ice. Vol. 1, Part 2. Sapporo, Hokkaido University. Institute of Low Temperature Science, 857-874.

Salm, B. 1971. On the rheological behavior of snow under high stresses. Contrib. Inst. Low Temp. Sci., Ser. A 23, 1-43.

Salm, B. 1975. Constitutive equation for creeping snow. International Association of Hydrological Sciences Publication 114 (Symposium at Grindelwald 1974 - Snow Mechanics), 222-235.

Salm, B. 1977. Eine Stoffgleichung für die Kriechende Verformung von Schnee. (Ph.D. thesis, Eidgenössische Technische Hochschule, Zürich.)

Scapozza, C. and P. Bartelt. 2003. Triaxial tests on snow at low strain-rate. Part II. Constitutive behaviour. f. Glaciol., 49(164), 91-101.

Scapozza, C. and P. Bartelt. In press. The influence of temperature on the small-strain viscous deformation mechanics of snow: a comparison with polycrystalline ice. Ann. Glaciol., 37.

Schneebeli, M., C. Pielmeier and J. B. Johnson. 1998. Measuring snow microstructure and hardness using a high resolution penetrometer. Cold Reg. Sci. Technol., 30(1-3), 101-114.

Schweizer, J. 1998. Laboratory experiments on shear failure of snow. Ann. Glaciol., 26, 97-102.

Von Moos, M. 2000. Zusammenstellung der Versuchresultate der Experimente mit dem schneemechanischen Triaxialapparat in den Wintern 1997/98 and 1998/99. Zürich. Zürich, Swiss Federal Institute of Technology. Institute of Geotechnical Engineering. (Internal Report 442/4.)

Watanabe, Z. 1980. Tensile strain and fracture of snow. F. Glaciol., 26(94), $255-262$.

Yong, R. N. and M. Fukue. 1977. Performance of snow in confined compression. Fournal of Terramechanics, $14(2), 59-82$.

MS received 7 September 2001 and accepted in revised form 10 December 2002 